\title{
Phylogeography and environmental diversification of a highly adaptable marine amphipod, Gammarus duebeni
}

\author{
J Rock ${ }^{1}$, J Ironside ${ }^{2}$, T Potter ${ }^{1}$, NM Whiteley ${ }^{1}$ and DH Lunt ${ }^{3}$ \\ ${ }^{1}$ School of Biological Sciences, University of Wales, Bangor, Gwynedd, UK; ${ }^{2}$ Institute of Biological Sciences, University of Wales, \\ Aberystwyth, Ceredigion, UK and ${ }^{3}$ Department of Biological Sciences, University of Hull, Hull, UK
}

\begin{abstract}
Genetic diversity and phylogeographic population structure in the gammarid amphipod, Gammarus duebeni, were investigated across its broad latitudinal distribution in the NE and NW Atlantic by analysis of mitochondrial DNA sequence. Gammarus duebeni has exceptional tolerance of salinity change and inhabits environments ranging from marine to freshwater. The longstanding debate on whether there are distinct marine and freshwater subspecies was assessed by sampling populations from sites characterized by different salinities. Our sequence data demonstrates that
\end{abstract}

there are two major lineages, with little internal geographic structuring. Evidence is provided to suggest a pre-glacial divergence of these two clades, involving segregation between a region historically associated with the freshwater form and the majority of the marine localities on both sides of the Atlantic. A modern contact zone between the marine and freshwater forms is proposed in western Britain.

Heredity (2007) 99, 102-111; doi:10.1038/sj.hdy.6800971; published online 11 April 2007

Keywords: mtDNA; Gammarus duebeni; amphipod; population structure; phylogeography; taxonomy

\section{Introduction}

Rocky shore environments in the North Atlantic are characterized by dramatic cyclical and stochastic fluctuations in a range of physical parameters. In addition to these short-term fluctuations, the intertidal organisms that inhabit this challenging environment have also been subject to significant environmental fluctuations over evolutionary time scales. In particular, Pleistocene climate cycles (ice ages) are predicted to have had dramatic impacts upon the geographical ranges of North Atlantic coastal species (Avise, 1992; Graham et al., 2003).

Previous case studies indicate that the effect of Pleistocene climate cycles upon the genetic diversity of North Atlantic coastal species was far from uniform (e.g. Wares and Cunningham, 2001; Young et al., 2002; Luttikhuizen et al., 2003; Riginos et al., 2004; Roman and Palumbi, 2004; Addison and Hart, 2005; Jolly et al., 2005; Provan et al., 2005). Some of these species show a phylogeographic structure characterized by shallow genetic divergence between haplotypes, with no geographic pattern to their distribution and no genetic subdivision between the NW and NE Atlantic. This pattern has been attributed (Ingólfsson, 1992) to the fact that, on the European side, rocky shore taxa displaced by temperature or ice, would encounter suitable refugia in

Correspondence: Dr J Rock, School of Biological Sciences, University of Wales Bangor, Deiniol, Bangor, Gwynedd LL57 2UW, UK.

E-mail: j.rock@bangor.ac.uk

Received 18 August 2006; revised 20 December 2006; accepted 16 February 2007; published online 11 April 2007 rocky habitats further south. On the NW Atlantic coast, however, there is relatively little suitable rocky habitat in the south, and it has been suggested that this might lead to the extinction of NW Atlantic populations after displacement from northern latitudes. Several examples support this process with the pattern of genetic diversity in marine species indicating a recent NE Atlantic origin for NW Atlantic haplotypes (Wares, 2001a; Wares and Cunningham, 2001). A second, contrasting phylogeographic pattern is geographic structuring of distinct haplotypes (Riginos et al., 2004; Roman and Palumbi, 2004; Provan et al., 2005), frequently involving division into NE versus NW Atlantic populations, as well as additional geographically restricted lineages. Such an occurrence of genetically distinct and geographically isolated populations in the Northern Atlantic is often considered indicative of survival and divergence in isolated refugia during the Pleistocene. A phylogeographic approach then, even if revealing very limited structure, can reveal much about the Pleistocene history of both species and regions.

Gammarid amphipods are a large and diverse group of crustaceans that are exceptionally abundant in the marine coastal environment of both the eastern and western North Atlantic, where they form an important component of aquatic food webs (Bousfield, 1978). The Gammarus genus, in particular, is highly adaptable, with species occupying intertidal and subtidal habitats and extending into estuaries and freshwater. Much of gammarid systematics remains unresolved, despite a century of detailed morphological taxonomy (e.g. Kinne, 1954; Holmes, 1975) and analysis of allozymes (Bulnheim 
and Scholl, 1980; Kolding and Simonsen, 1983; Siegismund et al., 1985; Skadsheim and Siegismund, 1986; Kane et al., 1992; Müller et al., 2000). Modern molecular techniques for determining phylogenetic relationships have, to date, been used on only a few gammarids, and these are almost exclusively from freshwater habitats (Meyran et al., 1997, 1998; Meyran and Taberlet, 1998; Sherbakov et al., 1999; Müller, 2000; Englisch et al., 2003; Macdonald et al., 2005; Kelly et al., 2006).

The gammarid amphipod Gammarus duebeni (Liljeborg) has a particularly remarkable capacity to tolerate a wide range of salinity, from freshwater to hypertonic solutions of 70\% (see Lockwood, 1992). Gammarus duebeni can be found in both marine and landlocked freshwater environments, and it has long been debated whether differentiation between these populations actually defines subspecies level divergence. The first proposal for a freshwater form $(\alpha$, localized but abundant in rivers and lakes of Ireland and Brittany) and a brackish-marine form $(\beta)$ (Reid, 1939) was later formalized by splitting G. duebeni into two subspecies (Stock and Pinkster, 1970): G. d. celticus, the freshwater form, and G. d.duebeni, the marine form. The original argument for subspecies-level differentiation in G. duebeni was based upon observations of higher tolerances for hypoosmotic conditions in individuals from landlocked freshwater populations than in individuals from marine populations (Sutcliffe, 1971; but see Lockwood, 1992; Sutcliffe, 2000). However, subsequent laboratory experiments demonstrate that both marine and freshwater forms are capable of acclimating to a broad and overlapping range of salinities (Sutcliffe, 1978). Intermediate osmoregulatory capabilities also occur in individuals from freshwater sites in close proximity to a marine influence (i.e. streams on small islands or peninsulas including the Isle of Man, Cornwall and W Scotland). This suggests that marine and freshwater forms arise from a common gene pool by phenotypic plasticity (Sutcliffe, 2000). Recent physiological studies have, however, demonstrated that the ability of G.d. duebeni to adjust whole animal water permeability is far superior to the capabilities of G.d.celticus (C Lloyd Mills, personal communication), although it remains to be confirmed whether these osmoregulatory differences have any genetic basis.

Holmes (1975) examined 121 morphological features and failed to identify any that reliably distinguished between marine and freshwater forms of G. duebeni. However, other researchers have differentiated marine and freshwater forms on the basis of differences in leg morphology (Pinkster et al., 1970; Stock and Pinkster, 1970). Their results indicate that marine populations of $G$. duebeni have relatively high width to length ratios of the merus segment on pereopod 7 (mean $\log \mathrm{W} / \mathrm{L}$ $\geqslant 0.74$ ) with the length being less than twice the width, whereas freshwater populations (Ireland and Brittany) have lower ratio values $(\leqslant 0.73)$, indicating a narrower overall leg segment (see Sutcliffe, 2000). However, intermediate values were again obtained for certain freshwater populations from small islands and peninsulas, suggesting that variation may demonstrate phenotypic plasticity in response to environmental variation (e.g. thermal regime and its effects on differential growth rate) rather than genetic divergence.
Individuals from marine and freshwater G. duebeni populations will successfully interbreed under laboratory conditions (Stock and Pinkster, 1970). A constraint on interbreeding between G. d. duebeni and G. d. celticus was proposed for some natural populations because of slight differences in breeding season (Hynes, 1954). However, freshwater populations in Ireland and Brittany occupy the warmest sites in the species' entire N Atlantic distribution and it has not been determined whether differences in reproductive cycles persist under common thermal regimes. Although a molecular study using allozyme electrophoresis also failed to distinguish between the putative subspecies (Bulnheim and Scholl, 1980), the degree of genetic divergence between the two forms of $G$. duebeni and its relationship to the morphological and physiological differences outlined above, remains to be resolved.

In addition to its ecological importance as a component of multiple aquatic energy cycles, G. duebeni has recently assumed importance as a model system for studies of environmental sex determination (ESD) (McCabe and Dunn, 1997), parasitic sex-ratio distortion (Ironside et al., 2003), parasite-mediated competition (MacNeil et al., 2004a) and intra-guild predation (MacNeil et al., 2004b). Recent evidence has indicated significant genetic variation within G. duebeni for ESD (Dunn et al., 2005) and for host-parasite coevolution (Hatcher et al., 2005) and future research within these areas will benefit from information relating to the genetic structure and evolutionary history of G. duebeni populations. This study uses mitochondrial DNA (mtDNA) sequence data to characterize the phylogeography of $G$. duebeni in the North Atlantic, and to evaluate levels of genetic divergence corresponding to freshwater and marine populations. The findings of this investigation resolve a long-running debate concerning G. duebeni taxonomy and further our understanding of how Pleistocene glacial cycles affected the genetic variation of intertidal and freshwater organisms.

\section{Materials and methods}

\section{Sample collection}

Gammarus duebeni were collected from populations on eastern $(n=3)$ and western $(n=15)$ sides of the $\mathrm{N}$ Atlantic, across a range of latitudes (Table 1, Figure 1). Individuals were collected with fine-meshed dip nets from under stones in the inter-tidal zone. G. duebeni is typically found in habitats where freshwater crosses the intertidal zone (e.g. streams and other low output natural runoffs, or storm drains and ditches). At low tide, populations in these habitats can encounter hypo-saline water owing to freshwater input, or hyper-saline water owing to evaporation, but are generally considered to be marine populations. In Wales, one collection (A Rhoscolyn) was also made from storm pools above the mean high water mark. In addition, several samples were obtained from freshwater sources of constant low salinity $(0 \%)$ in Ireland (A: River Lagan; B: Lough Neagh) and on the Isle of Man (from a stream 2.5 miles inland without brackish influence; J Ironside, personal observation). All specimens were stored in $95 \%$ ethanol following collection. At two locations (Isle of Skye and Wales, Beaumaris), reference specimens were collected for 
confirmation of species identification by morphological comparison after Lincoln (1979) (M Lohe, Natural History Museum, London, personal communication); these individuals appear in subsequent analyses in this study as 'Wales mus' and 'Isle of Skye mus'.

\section{Extraction/PCR/sequencing}

MtDNA was extracted by either the Chelex method (Walsh et al., 1991) or by the alkaline lysis procedure (Hot Shot; Truett et al., 2000) on 1-3 legs of each specimen. A fragment of the cytochrome $c$ oxidase subunit 1 (CO1) gene was amplified using universal primers (LCO1490: 5'-GGTCAACAAATCATAAAGATATTGG-3', HCO02198: 5'-TAAACTTCAGGGTGACCAAAAAATCA-3'; Folmer et al., 1994). Each $20 \mu \mathrm{l}$ reaction contained 1-3 $\mu \mathrm{l}$ DNA, 1X PCR buffer (NH2, Bioline), $2 \mathrm{mM} \mathrm{MgCl}^{2}, 80 \mathrm{mM}$ deoxynucleoside triphosphate mix, $0.5 \mu \mathrm{M}$ of each primer and 0.6 U DNA polymerase. Amplification consisted of an initial denature for $3 \mathrm{~min}$ at $94^{\circ} \mathrm{C}$, followed by 35 cycles of $45 \mathrm{~s}$ at $94^{\circ} \mathrm{C}, 1 \mathrm{~min}$ at $50^{\circ} \mathrm{C}, 2 \mathrm{~min}$ at $72^{\circ} \mathrm{C}$; cycling ended

Table 1 Details of sampling locations, size $(n)$ and population codes

\begin{tabular}{|c|c|c|c|}
\hline Population & Latitude and longitude & $\mathrm{n}$ & Code \\
\hline \multicolumn{4}{|l|}{ Eastern Atlantic } \\
\hline England, Plymouth, & $502300 \mathrm{~N} 041000 \mathrm{~W}$ & 5 & Ply \\
\hline Wales: Bangor & $531351 \mathrm{~N} 040814 \mathrm{~W}$ & 8 & Wsl \\
\hline A Rhoscolyn & $531429 \mathrm{~N} 043538 \mathrm{~W}$ & 3 & Wrcsp \\
\hline B Rhoscolyn & $531435 \mathrm{~N} 043529 \mathrm{~W}$ & 2 & Wrcst \\
\hline Beaumaris & $531703 \mathrm{~N} 040424 \mathrm{~W}$ & 2 & Wmus \\
\hline Isle of Man & $540549 \mathrm{~N} 044218 \mathrm{~W}$ & 5 & IoM \\
\hline $\begin{array}{r}\text { Ireland: } A \\
B\end{array}$ & $543943 N 062411 \mathrm{~W}$ & $\begin{array}{l}2 \\
5\end{array}$ & $\begin{array}{l}\text { Ireland } A \\
\text { Ireland } B\end{array}$ \\
\hline Scotland: S. (Forth Clyde) & $554600 \mathrm{~N} 045600 \mathrm{~W}$ & 5 & Ssc \\
\hline Isle of Skye & $572400 \mathrm{~N} 061200 \mathrm{~W}$ & 8 & IoS \\
\hline Poland, Gdynia & $543104 \mathrm{~N} 183211 \mathrm{E}$ & 2 & Gdy \\
\hline Sweden & $574300 \mathrm{~N} 115800 \mathrm{E}$ & 1 & Swe \\
\hline Faroes & $620100 \mathrm{~N} 064600 \mathrm{~W}$ & 5 & Far \\
\hline Norway: Trondheim & $632500 \mathrm{~N} 102500 \mathrm{E}$ & 5 & Trn \\
\hline Troms $\varnothing$ & $694000 \mathrm{~N} 185800 \mathrm{E}$ & 11 & Tro \\
\hline \multicolumn{4}{|l|}{ Western Atlantic } \\
\hline Rhode Island & $412900 \mathrm{~N} 711900 \mathrm{~W}$ & 11 & RI \\
\hline Maine & $434000 \mathrm{~N} 701500 \mathrm{~W}$ & 3 & $\mathrm{Me}$ \\
\hline Newfoundland & $473400 \mathrm{~N} 524300 \mathrm{~W}$ & 5 & NF \\
\hline
\end{tabular}

The landlocked freshwater populations (Ireland) are shown in italics. with a final extension time of $10 \mathrm{~min}$ at $72{ }^{\circ} \mathrm{C}$. Amplicons were purified using ExoSAP (Fermentas) and sequenced bi-directionally on a Beckman Coulter CEQ 2000XL DNA Analysis System. Sequences were aligned and edited in CodonCode Aligner v. 1.3.4 (CodonCode, Dedham, MA, USA).

\section{Phylogenetic analyses}

Analyses of relationships among taxa were conducted using neighbour joining, maximum parsimony, maximum likelihood and Bayesian inference analyses in Paup 4.0b (Swofford, 2000), PHYML v2.4.4 (Guindon and Gascuel, 2003) and MrBayes v3.1.1 (Ronquist and Huelsenbeck, 2003). The model of nucleotide substitution was determined using Modelgenerator (Keane et al., 2004). Bayesian inference was conducted with data partitioned by codon positions for $2 \times 10^{6}$ generations (sample freq $=100$, burnin $=2000$ ). Substitution matrix was set at General Time Reversible (nst =6) with other parameters optimized as part of the run. A Nested Clade Phylogeographical Analysis (NCPA) was conducted after Templeton's (2004) most current method to further discriminate between the contemporary processes and historical events. The haplotype cladogram was constructed using Templeton, Crandall, sing (TCS); (Templeton et al., 1992; Clement et al., 2000) and Geodis (Posada et al., 2000) provided tests of relationships between relative clade distances.

\section{Comparison of limb morphology}

In order to test whether genetic divergence corresponded to divergence in morphological characters used to differentiate the two putative G. duebeni subspecies, a comparison of limb morphology was performed between individuals collected from the Bangor and A Rhoscolyn populations. These populations are located in close proximity and experience similar environmental conditions but molecular analysis partitions the two populations between the two major genetic clades (see Results for sequence variation and divergence of haplotypes). A random sample of 50 individuals was collected from each population and width to length ratios of the merus segment on pereopod 7 were measured to the nearest 10th of a millimetre using a dissecting microscope and graticule eyepiece. Significance was tested using analysis of covariance (ANCOVA) with total body length as a covariate.

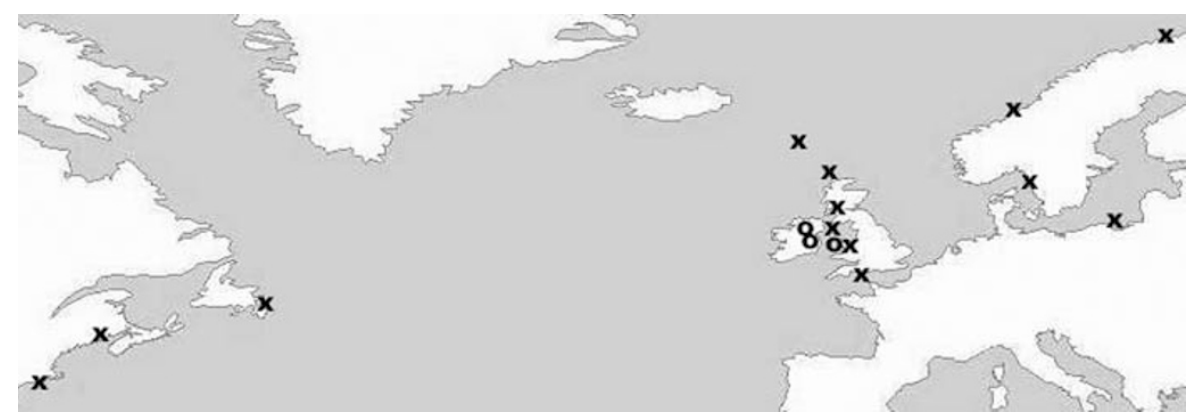

Figure 1 Map of sampling sites for marine (x) and freshwater (o) sites in the North Atlantic. 
Table 2 Distribution of the 11 haplotypes among the 88 individuals collected from 18 different populations of Gammarus duebeni (see Table 1 for nomenclature of populations)

\begin{tabular}{|c|c|c|c|c|c|c|c|c|c|c|c|}
\hline \multirow[t]{2}{*}{ Population } & \multicolumn{11}{|c|}{ Haplotypes } \\
\hline & 1 & 2 & 3 & 4 & 5 & 6 & 7 & 8 & 9 & 10 & 11 \\
\hline England, Plymouth & & & & & & 5 & & & & & \\
\hline Wales: Bangor & & & & & 8 & & & & & & \\
\hline A Rhoscolyn & & 1 & & & 1 & & & & 2 & & \\
\hline B Rhoscolyn & & & & & & & & & 2 & & \\
\hline Beaumaris & 1 & & & & & & & & & & \\
\hline Isle of Man & & 3 & & & & & & & & 2 & \\
\hline Ireland: Ireland $A$ & & & & & 2 & & & & & & \\
\hline Ireland $B$ & & & & & & & 5 & & & & \\
\hline Scotland: S. (Forth Clyde) & 1 & 1 & & & & & & & 3 & & \\
\hline Isle of Skye & 5 & 2 & & & & & & & & & 1 \\
\hline Poland, Gdynia & 1 & 1 & & & & & & & & & \\
\hline Sweden & 1 & & & & & & & & & & \\
\hline Faroes & 5 & & & & & & & & & & \\
\hline Norway: Trondheim & 3 & 2 & & & & & & & & & \\
\hline Troms $\varnothing$ & & 1 & 10 & & & & & & & & \\
\hline Rhode Island & 2 & 5 & & & & & & 4 & & & \\
\hline Maine & & & & 3 & & & & & & & \\
\hline Newfoundland & & & & 5 & & & & & & & \\
\hline
\end{tabular}

The landlocked freshwater populations (Ireland) are shown in italics.

The nucleotide sequences of these haplotypes are available from international sequence databases under accession numbers EF468643EF468653.

Table 3 HKY distances within haplotypes

\begin{tabular}{|c|c|c|c|c|c|c|c|c|c|c|}
\hline & Hap1 & Hap2 & Hap3 & Hap4 & Hap5 & Hap6 & Hap7 & Hap8 & Hap9 & Hap10 \\
\hline Hap1 & - & & & & & & & & & \\
\hline Hap2 & 0.0016 & - & & & & & & & & \\
\hline Hap3 & 0.0046 & 0.0031 & - & & & & & & & \\
\hline Hap4 & 0.0015 & 0.0031 & 0.0061 & - & & & & & & \\
\hline Hap5 & 0.0388 & 0.0411 & 0.0372 & 0.0404 & - & & & & & \\
\hline Hap6 & 0.0031 & 0.0016 & 0.0046 & 0.0046 & 0.0411 & - & & & & \\
\hline Hap7 & 0.0431 & 0.0447 & 0.0414 & 0.0447 & 0.0031 & 0.0454 & - & & & \\
\hline Hap8 & 0.0031 & 0.0016 & 0.0046 & 0.0046 & 0.0409 & 0.0031 & 0.0453 & - & & \\
\hline Hap9 & 0.0033 & 0.0016 & 0.0016 & 0.0049 & 0.0382 & 0.0032 & 0.0417 & 0.0033 & - & \\
\hline Hap10 & 0.0031 & 0.0015 & 0.0046 & 0.0046 & 0.0427 & 0.0031 & 0.0464 & 0.0031 & 0.0032 & - \\
\hline Hap11 & 0.0404 & 0.0427 & 0.0388 & 0.0420 & 0.0015 & 0.0427 & 0.0047 & 0.0425 & 0.0399 & 0.0444 \\
\hline
\end{tabular}

Haplotypes for freshwater populations are in bold and comparisons between fresh and marine forms are shown in italics.

\section{Results}

\section{Sequence variation and divergence of haplotypes}

A $608 \mathrm{bp}$ fragment of the CO1 gene was obtained for a total of 88 specimens from the 18 populations studied. Average base composition for this sequence was $23 \% \mathrm{~A}$, $36 \%$ T, 22\% C and 20\% G. Overall nucleotide diversity $(\mathrm{Pi})$ was 0.0191 , and 0.003 within each of the marine and freshwater populations (described below). Thirty variable nucleotide sites were identified $(5 \%)$ of which 23 were parsimony informative mutations. Eleven haplotypes were distinguished (Table 2). Pairwise comparison of haplotype sequence divergence (measured by Hasegawa, Kishino, Yano (HKY) distances; Table 3) revealed a genetic distance ranging from 0.0015 (between haplotypes 1 and 4, 2 and 10, and 5 and 11) to 0.0464 (between haplotypes 7 and 10). For maximum likelihood and neighbour-joining analyses, HKY was determined to be the best-fit model of nucleotide substitution (using the Akaike information criterion in Modelgenerator (Keane et al., 2004).

\section{Differentiation between freshwater and marine populations}

Phylogenies produced by maximum parsimony, maximum likelihood, neighbour-joining and Bayesian Inference had very similar topologies, revealing two distinct and well-supported clades (Figure 2). One clade included the two Irish freshwater populations, as well as one population from Wales (Bangor) from a typical marine habitat. The second major clade included all of the other marine populations, as well as one population 




Figure 2 Tree constructed by Maximum Likelihood Analysis for G. duebeni. Bootstrap analysis consisted of 1000 pseudoreplicates; nodes with $>70 \%$ support are marked with an asterisk. Haplotype assignment number (after Table 2) is given within a circle to the left of each bracket. 
from the previously described Isle of Man site (see Materials and methods). Within this clade, one marine population in Wales (Beaumaris) and one marine population in Scotland (Isle of Skye) contained single individuals with haplotypes belonging to first (freshwater) clade.

\section{Comparison of limb morphology}

Mean merus ratios were $0.72 \pm 0.11$ s.d. in the Bangor population sample and $0.67 \pm 0.08$ s.d. in the A Rhoscolyn population sample. No significant difference in merus ratio values was found $\left(F_{1,96}=1.22, P=0.47\right.$; with body size used as a covariate to control for the significant relationship between body length and merus width:length; $F_{2,96}=15.99, P=0.0001$ ) and no significant interspecific difference was found for the interaction between body size and merus dimensions $\left(F_{1,96}=3.55, P=0.063\right.$; ANCOVA).

\section{Geographic distribution of haplotypes}

No sequence variation (homogeneity) was observed within nine populations: Maine, Newfoundland, Faroes, Wales Bangor, Sweden, Ireland B, Ireland A, Wales B and Plymouth (Table 2; although sample sizes for the latter three were all small and may compromise analyses of diversity). In addition, Plymouth and Ireland B were fixed for a unique haplotype, whereas all others possessed a haplotype shared with at least one other population. Four haplotypes were restricted to single populations: hap 3 in Troms $\varnothing$, hap 11 in Isle of Skye, hap 10 in the Isle of Man and hap 8 in Rhode Island. Two haplotypes were shared across the Atlantic (amphiAtlantic), whereas seven were exclusive to the NE Atlantic and two were exclusive to the NW Atlantic.

Two separate haplotype networks were generated by TCS, as this programme is only able to resolve haplotype connections with at least $95 \%$ parsimony $(<11$ mutational steps) (Figure 3). The two separate networks correspond to those haplotypes mainly associated with the freshwater Ireland samples (hereafter referred to as the freshwater clade) and those haplotypes associated with the predominant marine populations (hereafter, the marine clade). Biological NCPA interpretation of the structuring of three internal clades for the larger marine clade invoked both recent and historical processes. Past fragmentation and subsequent range expansion, with the potential of contributions from long distance colonization, characterize the divergence of both the Troms $\varnothing$ population (hap 3) from the hap 9 assemblage (S Scotland, Wales A and B) and the Newfoundland/Maine populations (hap 4) from the amphi-Atlantic grouping (hap 1, Table 2, Figure 2). A process involving restricted gene flow with some long distance dispersal was invoked for divergence between the basal amphiAtlantic grouping (hap 2; see Table 2, Figure 2) and populations in Rhode Island (hap 8), Plymouth (hap 6) and Isle of Man (hap 10). Divergence within the overall marine clade was characterized by restricted gene flow with isolation by distance from the ancestral haplotype (hap 2). Ancestral status of this haplotype as the source of genetic diversity is supported under coalescence theory (Crandall and Templeton, 1993) by its high frequency of occurrence in different populations and wide geographic distribution.

\section{Discussion}

Phylogenetic significance of mtDNA variation: $G$. $d$. duebeni and G. d. celticus

The results of this study reveal significant intraspecific differentiation (4\% sequence divergence) for G. duebeni. Two major clades were resolved by a range of phyloge-
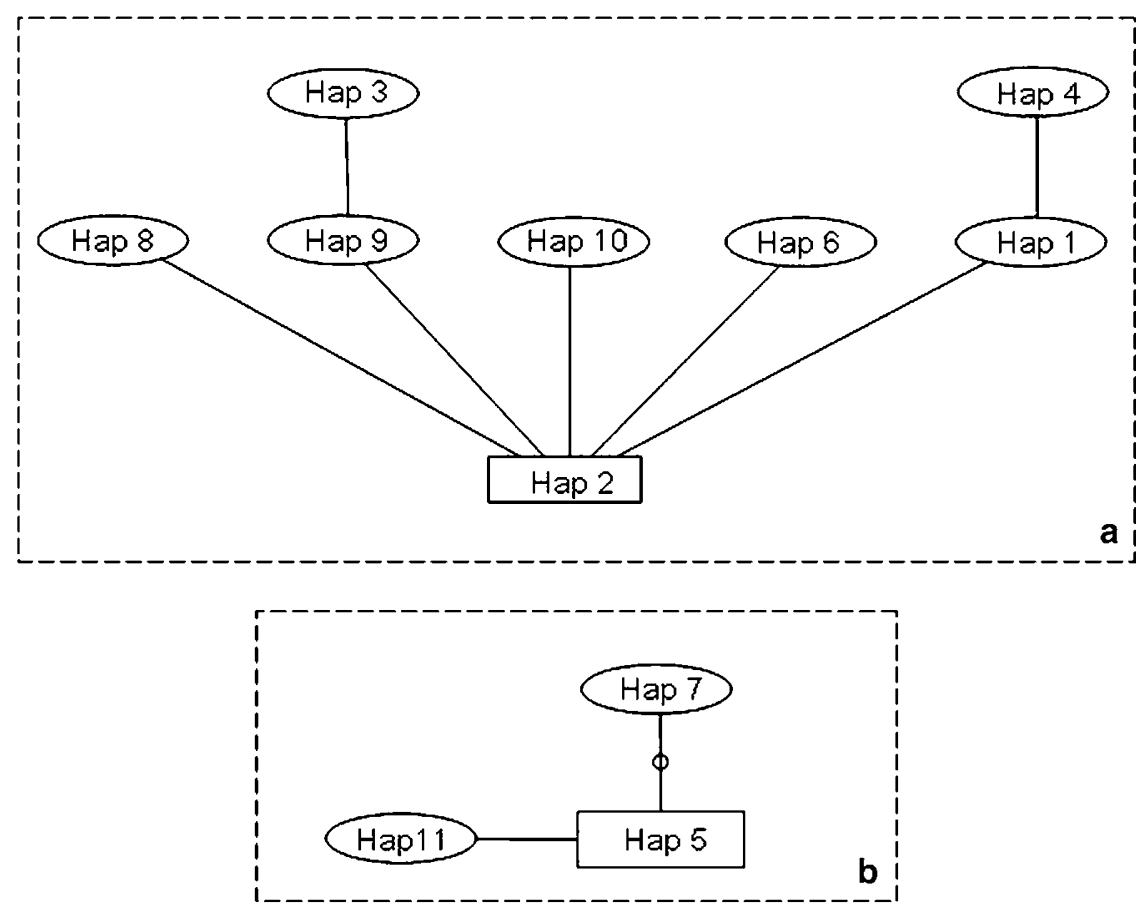

Figure 3 Network of the 11 G. duebeni haplotypes. (a) Represents the marine form, and (b) represents the freshwater form. 
netic analyses, one of which contained the two landlocked Irish freshwater populations, and very little internal structure or divergence $(0.1-0.4 \%)$ was detected within each clade. Varying degrees of intraspecific diversity have been previously reported for other, mainly freshwater, gammarids. The degree of intraspecific diversity observed for G. duebeni compares favourably with that of G. lacustris (Sars) (0.2-1.6\%; Meyran and Taberlet, 1998) and for populations of G. fossarum (Koch) distributed within a narrow geographic area varying in environmental calcium ( $\approx 0.3-4.7 \%$; Meyran et al., 1998). On a broader scale, populations of G. fossarum distributed across Europe are highly divergent (8-11\%; Meyran et al., 1997; Müller, 2000) and a similar level of divergence (5-9\%) was used to differentiate subspecies in G. pulex (Linnaeus) (Hadfield, 2002). Molecular variance in G. duebeni does in fact approach the minimum interspecific distances reported for other amphipod taxa (4-18\%; France and Kocher, 1996), although minimum distances often appear to be higher for gammarids (9-12\%; Meyran et al., 1997; Kelly et al., 2006). Thus, values of $4 \%$ divergence within $G$. duebeni might arguably be substantial enough to indicate divergence into two biological species. However, although the level of divergence between congenerics in other crustaceans may even be $<4 \%$ (see Müller, 2000) (with typical among-genus level of divergence of at least 20\%; Cunningham et al., 1992), preliminary phylogenetic data from a broad sampling of marine Gammarus indicates that $24 \%$ sequence divergence is common between species in the $\mathrm{N}$ Atlantic (J Rock and DH Lunt; unpublished observation). Understanding whether the lineages identified in this work represent full species or intraspecific units will require additional work that considers mating compatibility, gene flow at nuclear loci and ecological and physiological divergence. Such approaches are currently ongoing (Rock et al., unpublished). The depth of differentiation between the two central clades in G. duebeni suggests that it is a fairly old divergence. Although there is no molecular clock specifically calibrated for amphipods, Quek et al. (2004) surveyed the literature for arthropod COI rates calibrated by fossils or biogeography and reported rates ranging from 1.3 to $1.9 \%$ per million years. Thus, although precise dating will probably require fossil calibrations and more sophisticated analyses of additional data, it seems likely that divergence between the $G$. duebeni clades is much older than the last glacial maximum (LGM) and may be early Pleistocene or Pliocene with the lineages having experienced separate phylogeographic histories during the Pleistocene climate cycles. Based on both historical precedence (Sutcliffe, 2000) and physical barriers to a marine influence, it is reasonable to assume that the Irish populations sampled in this study represent the putative freshwater subspecies, G. d. celticus. Our results indicate that populations from this region are indeed associated with a haplotype highly divergent from the majority of marine populations sampled in the $\mathrm{N}$ Atlantic. The observed values of sequence divergence ( $4 \%$ between versus $0.3 \%$ within clades) provide the first molecular support for G. duebeni duebeni and G. duebeni celticus.

Preliminary morphological data on merus width:length ratios for $G$. d. duebeni and G. d. celticus collected from nearby, environmentally similar populations in Wales (Bangor and A Rhoscolyn) does not support the hypothesis that G. $d$. celticus has lower merus ratios. Indeed, considering the combined effects of allometric growth patterns (Sutcliffe, 1972, 2000) and interpopulation variation in thermal environment in G. duebeni, it is doubtful that any morphological features can be considered diagnostic for differentiating the two subspecies.

\section{Geographic distribution and molecular variation in the G. duebeni complex}

Although divergence of $G$. duebeni subspecies is likely to fall well before the LGM ( 18-20 kya) for both eastern and western sides of the Atlantic, intra-lineage mtDNA variation in this taxon has undoubtedly been shaped by the ice ages. For G. d. duebeni, molecular diversity is low with haplotypes shared across broad geographic areas, including the coasts of both $\mathrm{N}$ America and Europe. Such a pattern is indicative of taxa experiencing postglacial expansion (Ibrahim et al., 1996; Hewitt, 2000; Fedorov et al., 2003; Lessa et al., 2003). A degree of genetic differentiation does exist among some populations, most noticeably at the species' latitudinal extremes (e.g. N: Troms $\varnothing$, Newfoundland, Maine; S: Plymouth), suggesting lack of gene flow owing to geographic isolation. Phylogeographic analyses (NCPA) indicated that the divergence of these populations was attributable to past fragmentation and subsequent range expansion, with some likelihood of contributions from long distance colonization. However, the source and directionality of these observed divergences remains unclear with the present data set. In general, however, we observe low genetic diversity even between Eastern and Western Atlantic populations, some sharing COI haplotypes. This is likely to indicate a recent shared history associated with a post-glacial expansion, such as has been observed in other N Atlantic coastal species (Wares, 2001b; Wares and Cunningham, 2001; Riginos et al., 2004). An intensive sampling effort will be required on both sides of the Atlantic to further characterize the subtleties of the historic processes of divergence in G. duebeni. Its broad distribution, ease of sampling and amenability to phylogeographic study makes G. duebeni a powerful system for study of patterns of $\mathrm{N}$ Atlantic recolonization. Further, this taxon exhibits marked tolerance for low temperatures, living in Arctic locations such as Troms $\varnothing$ (Lat $69^{\circ} 40^{\prime} \mathrm{N}$ ) where they are active in brackish waters of $-2{ }^{\circ} \mathrm{C}$, and is a priori a good candidate to survive the glacial maximum at northern latitudes. However, because our data indicates a very recent common ancestor for amphi-Atlantic populations, it seems unlikely that it has in fact persisted in northern areas throughout the Pleistocene. Study of such northern and cold-tolerant taxa is potentially a productive direction for phylogeographic studies aimed at better understanding the response of communities to climate cycles (Fedorov et al., 2003; Hewitt, 2004).

We have detected two genetic lineages of G. duebeni that appear to match closely the previously proposed subspecies (Reid, 1939; Stock and Pinkster, 1970). The pre-LGM divergence levels of $G$. d. celticus and G. $d$. duebeni however contradicts the suggestion that G. $d$. celticus represents a postglacial invasion of freshwater habitats by a marine form (Sutcliffe, 2000), suggesting instead that they possess a much more extensive independent history. Furthermore, expansive sampling 
of marine habitats around the $\mathrm{N}$ Atlantic revealed only one population of G.d. celticus in a marine intertidal site (Wales, Bangor), a site novel in its association with freshwater outflow from a decommissioned pumping station. We also found only one site in which a population of G. d. duebeni occupied a freshwater stream (Isle of Man), but this site's proximity to a marine influence suggests a case of upstream migration of a marine population. Taken together with the depth of the divergence between $G$. duebeni subspecies $(\sim 4 \%)$, and the apparent lack of biological barriers to gene flow (i.e. similarity in morphology and osmoregulatory ability), it seems that a physical barrier to gene flow must have remained in place for a considerable time. One possible scenario is that populations of $G$. duebeni were isolated during sea level fluctuations in the late Pliocene/early Pleistocene, when periods of extremely low sea levels caused coastal estuaries to drain. Some populations may then have persisted in freshwater refugia in the ice-free regions of Ireland, Brittany, and possibly in the extreme western isles and peninsulas of Wales, England and Scotland. (See Hänfling et al. (2002) for discussion of a glacial refugium for temperate/cold-tolerant species in the extreme southwest of England.) Concomitantly, other populations of G. duebeni may have persisted in a coastal refugium, presumably at more southerly latitudes (e.g. rocky shore habitat of the Iberian Peninsula).

The current data also provide preliminary evidence for several contemporary contact points, creating a potential for modern introgression between G. d. duebeni and G. $d$. celticus. In two instances, a freshwater haplotype was found for an individual sampled from populations that were otherwise marine in habitat type and haplotype (Isle of Skye; Wales, Beaumaris). It may be that sporadic storm events will occasionally flush $G$. $d$. celticus individuals downstream into the marine environment, where key traits including osmotic adaptability and longevity may provide a potential opportunity for interbreeding, albeit at a low frequency. A more likely explanation for the mixed Beaumaris population is its proximity to the previously described Bangor population, which is situated on the same strait and connected by high current interchange; few barriers to gene flow are obvious between the subspecies in these environments. However, the divergence levels between freshwater and marine forms of G. duebeni indicate that they may have independent histories spanning more than one glacial cycle. This lack of exchange of mitochondrial haplotypes, despite broad tolerance of osmotic conditions, indicates that there may well be a practical barrier to genetic exchange (whether behavioural, ecological or genetic). Further ecological, reproductive compatibility tests and genetic study with nuclear markers may help to clarify the mechanisms behind such a barrier and elucidate important processes of divergence and interchange between marine and freshwater communities.

\section{Acknowledgements}

This work was supported by the Natural Environment Research Council, UK (Grant 01319). We thank Christy Henzler, Jamie Dick and Ashley Edwards for their contribution of samples. Christine Mitchell assisted in the laboratory, and Hayley Suter in the field. Several anonymous reviewers provided valuable comments on the paper.

\section{References}

Addison JA, Hart MW (2005). Colonization, dispersal, and hybridization influence phylogeography of North Atlantic sea urchins (Strongylocentrotus droebachiensis). Evolution 59 : 532-543.

Avise JC (1992). Molecular population structure and the biogeographic history of a regional fauna: a case history with lessons for conservation biology. Oikos 63: 62-76.

Bousfield EL (1978). A revised classification and phylogeny of amphipod crustaceans. Trans $R$ Soc Can, Ser IV 16: 343-390.

Bulnheim H-P, Scholl A (1980). Evidence of genetic divergence between two brackish-water Gammaridean sibling species. Mar Ecol Prog Ser 3: 163-165.

Clement M, Posada D, Crandall KA (2000). TCS: a computer program to estimate gene genealogies. Mol Ecol 9: 10-1657.

Crandall KA, Templeton AR (1993). Empirical tests of some predictions from coalescent theory with applications to intraspecific phylogeny reconstruction. Genetics 134: 959-969.

Cunningham CW, Blackstone NW, Buss LW (1992). Evolution of king crabs from hermit crab ancestors. Nature 335: 539-542.

Dunn AM, Hogg JC, Kelly A, Hatcher MJ (2005). Two cues for sex determination in Gammarus duebeni: adaptive variation in environmental sex determination? Limnol Oceanogr 50: 346-353.

Englisch U, Coleman CO, Wägele JW (2003). First observations on the phylogeny of the families Gammaridea, Crangonyctidae, Melitidae, Niphargidae, Megaluropidae and Oedicerotidae (Amphipoda, Crustacea), using small subunit rDNA gene sequences. J Nat Hist 37: 2461-2486.

Fedorov VB, Goropashnaya AV, Jaarola M, Cook JA (2003). Phylogeography of lemmings (Lemmus): no evidence for postglacial colonization of Arctic from the Beringian refugium. Mol Ecol 12: 725-731.

Folmer O, Black M, Hoeh W, Lutz R, Vrijenhoek R (1994). DNA primers for amplification of mitochondrial cytochrome $C$ oxidase subunit I from diverse metazoan invertebrates. Mol Mar Biol Biotech 3: 294-299.

France SC, Kocher TD (1996). Geographic and bathymetric patterns of mitochondrial $16 \mathrm{~S}$ rRNA sequence divergence among deep-sea amphipods, Eurythenes gryllus. Mar Biol 126: 633-643.

Graham MH, Dayton PK, Erlandson JM (2003). Ice ages and ecological transitions on temperate coasts. TREE 18: 33-40.

Guindon S, Gascuel O (2003). A simple, fast, and accurate algorithm to estimate large phylogenies by maximum likelihood. Syst Biol 52: 696-704.

Hadfield S (2002). Genetic structure and colonisation history of European and UK populations of Gammarus pulex. PhD thesis, University of Hull.

Hänfling B, Hellemans B, Volckaert FAM, Carvalho GR (2002). Late glacial history of the cold-adapted freshwater fish Cottus gobio, revealed by microsatellites. Mol Ecol 11: 1717-1729.

Hatcher MJ, Hogg JC, Dunn AM (2005). Local adaptation and enhanced virulence of Nosema granulosis artificially introduced into novel populations of its crustacean host, Gammarus duebeni. Int J Parasitol 35: 265-274.

Hewitt GM (2000). The genetic legacy of the quaternary ice ages. Nature 405: 907-913.

Hewitt GM (2004). Genetic consequences of climatic oscillations in the Quaternary. Philos Trans R Soc Lond B 359: 183-195.

Holmes JMC (1975). A comparison of numerical taxonomic techniques using measurements on the genera Gammarus and Marinogammarus (Amphipods). Biol J Linn Soc 7: 183-214.

Hynes HBM (1954). The ecology of Gammarus duebeni Lilljeborg and its occurrence in fresh water in western Britain. J Anim Ecol 23: 38-84. 
Ibrahim KM, Nichols RA, Hewitt GM (1996). Spatial patterns of genetic variation generated by different forms of dispersal during range expansion. Heredity 77: 282-291.

Ingólfsson A 1992. The origin of the rocky shore fauna of Iceland and the Canadian maritimes. J Biogeogr 19: 705-712.

Ironside JE, Smith JE, Hatcher MJ, Sharpe RG, Rollinson D, Dunn AM (2003). Two species of feminizing microsporidian parasite coexist in populations of Gammarus duebeni. J Evol Biol 16: 467-473.

Jolly MT, Jollivet D, Gentil F, Thiebaut E, Viard F (2005). Sharp genetic break between Atlantic and English Channel populations of the polychaete Pectinaria koreni, along the North Coast of France. Heredity 94: 23-32.

Kane TC, Culver DC, Jones RT (1992). Genetic structure of morphologically differentiated populations of the amphipod Gammarus minus. Evolution 46: 272-278.

Keane TM, Naughton TJ, McInerney JO (2004). ModelGenerator: Amino Acid and Nucleotide Substitution Model Selection. National University of Ireland: Maynooth, Ireland. http:// bioinf.nuim.ie/software/modelgenerator.

Kelly DW, MacIssac HJ, Heath DD (2006). Vicariance and dispersal effects on phylogeographic structure and speciation in a widespread estuarine invertebrate. Evolution $\mathbf{6 0}$ 257-267.

Kinne O (1954). Die Gammarus Arten der Kieler Bucht. Zoologische Jahrbucher (Syst) 82: 405-424.

Kolding S, Simonsen V (1983). Phylogenetic relationships of five species of the amphipod genus Gammarus. Zoolog Scripta 12 215-219.

Lessa EP, Cook JA, Patton JL (2003). Genetic footprints of demographic expansion in North America, but not Amazonia, during the Late Quaternaary. Proc Nat Acad Sci USA 100: 10331-10334.

Lincoln RJ (1979). British Marine Amphipods: Gammaridea. British Museum (Natural History): London.

Lockwood APM (1992). Gammarus duebeni: A flexible phenotype. In: Aldrich JC (ed). Quantified Phenotypic Responses in Morphology and Physiology. Japaga Publishers: Dublin. pp 215-227.

Luttikhuizen PC, Drent J, Baker AJ (2003). Disjunct distribution of highly diverged mitochondrial lineage clade and population subdivision in a marine bivalve with pelagic larval dispersal. Mol Ecol 12: 2215-2229.

MacDonald III KS, Yampolsky L, Duffy JE (2005). Molecular and morphological evolution of the amphipod radiation of Lake Baikal. Mol Phylogenet Evol 35: 323-343.

MacNeil C, Dick JTA, Johnson MP, Hatcher MJ, Dunn AM (2004a). A species invasion mediated through habitat structure, intraguild predation, and parasitism. Limnol Oceanogr 49: 1848-1856.

MacNeil C, Prenter J, Briffa M, Fielding NJ, Dick JTA, Riddell GE et al. (2004b). The replacement of a native freshwater amphipod by an invader: roles for environmental degradation and intraguild predation. Can J Fish Aq Sci 61: 1627-1635.

McCabe J, Dunn AM (1997). Adaptive significance of environmental sex determination in an amphipod. J Evol Biol 10: 515-527.

Meyran JC, Gielly L, Taberlet P (1998). Environmental calcium and mitochondrial DNA polymorphism among local populations of Gammarus fossarum (Crustacea, Amphipods). Mol Ecol 7: 1391-1400.

Meyran JC, Monnerot M, Taberlet P (1997). Taxonomic status and phylogenetic relationships of some species of the genus Gammarus (Crustacea, Amphipods) deduced from mitochondrial DNA sequences. Mol Phylogenet Evol 8: 1-10.

Meyran JC, Taberlet P (1998). Mitochondrial DNA polymorphism among alpine populations of Gammarus lacustris (Crustacea, Amphipods). Freshwat Biol 39: 259-265.

Müller J (2000). Mitochondrial DNA variation and the evolutionary history of cryptic Gammarus fossarum types. Mol Phylogenet Evol 15: 260-268.
Müller J, Partsch E, Link A (2000). Differentiation in morphology and habitat partitioning of genetically characterized Gammarus fossarum forms (Amphipoda) across a contact zone. Biol J Linn Soc 69: 41-53.

Pinkster S, Dennert AL, Stock B, Stock JH (1970). The problem of European freshwater populations of Gammarus duebeni Liljeborg, 1852. Bijdr Dierk 40: 116-147.

Posada D, Crandall KA, Templeton AR (2000). GeoDis: a program for the cladistic nested analysis of the geographical distribution of genetic haplotypes. Mol Ecol 9: 487-488.

Provan J, Wattier RA, Maggs CA (2005). Phylogeographic analysis of the red seaweed Palmaria palmate reveals a Pleistocene marine glacial refugium in the English Channel. Mol Ecol 14: 793-803.

Quek SP, Davies SJ, Itino T, Pierce NE (2004). Codiversification in an ant-plant mutualism: stem texture and the evolution of host use in Crematogaster (Formicidae: Myrmicinae) inhabitants of Macaranga (Euphorbiaceae). Evolution 58: 554-570.

Reid DM (1939). On the occurrence of Gammarus duebeni (Lillj.) (Crustacea, Amphipoda) in Ireland. Proc R Irish Acad B 45: 207-214.

Riginos C, Hickerson MJ, Henzler CM, Cunningham CW (2004). Differential patterns of male and female mtDNA exchange across the Atlantic ocean in the blue mussel, Mytilus edulis. Evolution 58: 2438-2451.

Roman J, Palumbi SR (2004). A global invader at home: population structure of the green crab, Carcinus maenas, in Europe. Mol Ecol 13: 2891-2898.

Ronquist F, Huelsenbeck JP (2003). MrBayes 3: Bayesian phylogenetic inference under mixed models. Bioinformatics 19: $1572-1574$.

Sherbakov DYU, Kamaltynov RM, Ogarkov OB, Väinölä R, Vainio JK, Verheyen E (1999). On the phylogeny of Lake Baikal amphipods in the light of mitochondrial and nuclear DNA sequence data. Crustaceana 72: 911-919.

Siegismund HRV, Simonsen S, Kolding S (1985). Genetic studies of Gammarus. I. Genetic differentiation between local populations. Hereditas 102: 1-13.

Skadsheim A, Siegismund HR (1986). Genetic relationships among north-western European Gammaridae (Amphipods). Crustaceana 51: 163-175.

Stock JH, Pinkster S (1970). Irish and French fresh water populations of Gammarus duebeni subspecifically different from brackish water populations. Nature 228: 874-875.

Sutcliffe DW (1971). Regulation of water and some ions in gammarids (Amphipods). I. Gammarus duebeni Lilljeborg from brackish water and fresh water. I Exp Biol 55: 325-344.

Sutcliffe DW (1972). An examination of subspecies differences in the merus of the fifth walking leg of the amphipod Gammarus duebeni Lilljeborg. Freshwat Biol 2: 203-216.

Sutcliffe DW (1978). Water chemistry and osmoregulation in some arthropods, especially Malacostraca. Freshwat Biol Assoc Ann Rep 46: 57-69.

Sutcliffe DW (2000). Subspecies, morphs and clines in the amphipods Gammarus duebeni from fresh and saline waters. Freshwat Forum 13: 60-75.

Swofford DL (2000). PAUP*. Phylogenetic Analysis Using Parsimony ( ${ }^{*}$ and Other Methods), Version 4. Sinauer Associates: Sunderland, Massachusetts.

Templeton AR (2004). Statistical phylogeography: methods of evaluating and minimizing inference errors. Mol Ecol 13: 789-809.

Templeton AR, Crandall KA, Sing CF (1992). A cladistic analysis of phenotypic associations with haplotypes inferred from restriction endonuclease mapping and DNA sequence data. III. Cladogram estimation. Genetics 132: 619-633.

Truett GE, Walker JA, Truett AA, Mynatt RL, Heeger P, Warman M (2000). Preparation of PCR-Quality DNA with Hot Sodium Hydroxide and Tris (HOTSHOT). Biotechniques 29: $52-54$. 
Walsh PS, Metzger DA, Higuchi R (1991). Chelex 100 as a medium for simple extraction of DNA for PCR-based typing from forensic material. Biotechniques 10: 506-513.

Wares JP (2001a). Biogeography of Asterias: North Atlantic climate change and speciation. Biol Bull 201: 95-103.

Wares JP (2001b). Intraspecific variation and geographic isolation in Idotea balthica (Isopoda: Valvifera). J Crust Biol 21: 1007-1013.
Wares JP, Cunningham CW (2001). Phylogeography and historical ecology of the North Atlantic intertidal. Evolution 55: 2455-2469.

Young AMC, Torres JE, Mack JE, Cunningham CW (2002). Morphological and genetic evidence for vicariance and refugium in the Atlantic and Gulf of Mexico populations of the hermit crab Pagurus longicarpus. Mar Biol 140: $1059-1066$ 